\title{
PENGARUH ORIENTASI CORPORATE SOCIAL RESPONSIBILITY (CSR) TERHADAP KINERJA SOSIAL PERUSAHAAN DENGAN KETIDAKPASTIAN LINGKUNGAN SEBAGAI VARIABEL PEMODERASI
}

\begin{abstract}
The objective of this research is to investigates the relationship of company's orientation toward social responsibility at small and medium enterprises to their social corporate performance. In addition, this research also examines the role of environmental uncertainty as the moderating variable in affecting the relationship of corporate social responsibility orientation and corporate social performance. Sample was taken from small and medium businesess in Jawa Tengah. Initial distribution of 300 set of questionnaires to SME respondents has resulted in final sample of 115 respondents that usable to the analysis stage. The results of this study show that company's ethical orientation has positive relationship with corporate social performance, while company's legal orientation has negative effect toward corporate social performance. Moreover, the presence of environmental uncertainty has resulted in two significant interactions with the two components of company's orientation. The interaction of environmental uncertainty and company's ethical orientation has negative relationship with corporate social performance. Similarly, the interaction of environmental uncertainty and company's legal orientation has positive relationship with corporate social performance.
\end{abstract}

Keywords: Corporate social responsibility; Corporate social responsibility orientation; kinerja social perusahaan; ketidakpastian lingkungan.

\section{PENDAHULUAN}

Tanggung jawab sosial perusahaan (Corporate Social Responsibility/CSR) memegang peranan penting sebagai bagian dari proses pembangunan yang berkelanjutan (sustainable development). Tanggung jawab sosial muncul sebagai dampak dari keputusan dan kegiatan organisasi bagi masyarakat dan lingkungannya yang diharapkan dapat memenuhi ekspektasi stakeholder sejalan dengan hukum yang berlaku dan norma masyarakat. Kesadaran akan tanggung jawab perusahaan yang tidak semata-mata berorientasi pada laba telah meningkat dengan pesat dalam satu dekade terakhir. Perubahan signifikan yang terjadi dalam beberapa tahun terakhir menumbuhkan kesadaran akan pentingnya isu sosial dan lingkungan. Sektor korporasi yang selama ini hanya memperhatikan aspek ekonomi dalam menjalankan kegiatannya semakin dituntut untuk lebih meningkatkan tanggung jawab sosial mereka.

Di Indonesia, praktek tanggung jawab sosial perusahaan baru mendapat perhatian signifikan dari pemerintah dengan keluarnya Undang-undang Perseroan Terbatas tahun 2007 tentang perseroan. Dalam pasal 74 undang undang tersebut dinyatakan bahwa perusahaan yang berkecimpung dalam bidang sumber 
daya alam wajib melaksanakan tanggung jawab sosial dan lingkungan. Meskipun demikian, upaya-upaya yang telah dilakukan oleh pemerintah tidak akan berhasil secara efektif jika tidak ditanamkan kesadaran sejak awal mengenai prinsip pertanggungjawaban terhadap publik sebagai dasar bagi tanggung jawab sosial termasuk bagi pihak pelaku bisnis usaha kecil dan menengah.

Berbicara mengenai usaha kecil dan menengah, sektor ini sebenarnya memegang peranan yang sangat strategis dalam mengemban amanat terhadap aspek tanggung jawab sosial (Perry dan Tower, 2009). Di Indonesia, lebih dari 50 juta pelaku usaha kecil dan menengah menjadi penyangga bagi tersedianya lapangan kerja bagi masyarakat dan bahkan menjadi pilar utama ekonomi kerakyatan. Sayangnya, perhatian pemerintah selama ini lebih tertuju pada investasi skala besar dan banyak fasilitas yang diberikan pada korporasi besar. Meskipun demikian, telah terbukti bahwa usaha kecil dan menengah merupakan sektor usaha yang tahan terhadap krisis ekonomi dan lebih mandiri dari ketergantungan terhadap bantuan pemerintah. Hal ini sebenarnya yang menjadi faktor utama mengapa peran sektor usaha kecil dan menengah tidak dapat diabaikan begitu saja.

Peran strategis dari usaha kecil dan menengah dalam menunjang perekonomian nasional tentu saja perlu memperhatikan aspek sosial dan lingkungan. Jika kesadaran akan tanggung jawab sosial dan lingkungan mulai dikembangkan dari awal maka ketika usaha bisnis mereka semakin berkembang akan dapat memberikan dorongan terhadap terciptanya pembangunan yang berkelanjutan. Berdasarkan semangat tersebut maka perlu dikenalkan aspek pertanggungjawaban sosial kepada usaha kecil dan menengah sebagai salah satu aktor penting dalam perekonomian nasional.

Sejalan dengan semangat untuk mengetahui seberapa besar orientasi para pelaku usaha kecil dan menengah terhadap tanggung jawab sosial perusahaan, maka penelitian ini menjadi relevan untuk dilakukan. Oleh karena itu penelitian ini akan mengkaji secara empiris mengenai persepsi pelaku usaha kecil dan menengah di Jawa Tengah tentang orientasi tanggungjawab sosial perusahaan dari bisnis yang mereka jalankan. Selanjutnya akan dianalisis mengenai dampak orientasi tersebut terhadap kinerja sosial perusahaan.

\section{TELAAH LITERATUR DAN PENGEMBANGAN HIPOTESIS}

\section{Konsep Corporate Social Responsibility (CSR)}

Istilah tanggung jawab sosial perusahaan (corporate social responsibility) memiliki definisi yang beragam. Ide dasar dari CSR tersebut sebenarnya adalah dunia usaha harus bertindak dan bertanggung jawab tidak hanya berdasarkan aspek ekonomi saja, tetapi juga terdapat konsekuensi non ekonomis. Dampak dari aktivitas perusahaan yang bersifat non ekonomis umumnya dilihat dari dampak sosial dan dampak terhadap lingkungan. Oleh karena itu dalam dasawarsa terakhir tuntutan dari masyarakat semakin kritis menyuarakan peran perusahaan dalam meningkatkan kesejahteraan sosial dan mengurangi dampak negatif terhadap lingkungan sekitar.

Masih terdapat perdebatan mengenai definisi pasti dari tanggung jawab sosial. Untuk keperluan penelitian ini, definisi dari Carrol $(1979,1999)$ menjadi rujukan utama dalam menjelaskan apa yang dimaksud dengan tanggung jawab sosial. Menurutnya pengertian tanggung jawab sosial adalah: 
The social responsibility of business encompasses the economic, legal, ethical, and discretionaryexpectations that society has of organisations at a given point in time.(Carrol, 1979).

Berdasarkan penjelasan tersebut maka terdapat empat komponen tanggung jawab sosial perusahaan, yaitu:

1. Tanggung jawab ekonomik, merefleksikan pandangan dasar bisnis yang harus produktif dan menguntungkan untuk bertahan menghadapi persaingan.

2. Tanggung jawab legal/ hukum, mengindikasikan bahwa tanggung jawab ekonomik dicapai sesuai dengan hukum dan aturan yang berlaku.

3. Tanggung jawab etika, tidak diwajibkan secara hukum tetapi merupakan ekspektasi masyarakat terhadap bisnis yang dijalankan dengan cara yang etis. Meliputi aturan tidak tertulis, norma-norma dan nilai-nilai yang tumbuh dan berkembang di masyarakat

4. Tanggung jawab diskresioner, merupakan peran yang dilakukan oleh perusahaan secara sukarela dan sebenarnya dilakukan atas kesadaran perusahaan itu sendiri karena tidak dituntut oleh masyarakat.

\section{Hubungan Orientasi Corporate Social Responsibility (CSR) dengan Kinerja Sosial Perusahaan}

Orientasi terhadap tanggung jawab sosial merupakan salah satu konsep yang banyak dibicarakan sejak lama dalam penelitian mengenai tanggung jawab sosial perusahaan. Salah satu pelopor dari konsep orientasi tanggung jawab sosial yang cukup populer adalah Aupperle (1984, 1985). Orientasi ini mencerminkan persepsi pihak-pihak yang berkepentingan terhadap nilai-nilai yang mendasari pengambilan keputusan oleh perusahaan yang terkait dengan tanggung jawab sosial. Secara teoretis dalam kaitannya dengan teori identitas sosial, dalam melakukan kategorisasi sosial maka setiap perusahaan termasuk UKM akan menempatkan usaha mereka sebagai bagian dari komunitas sosial yang terstruktur dan akan terus eksis (Hogg dan Abrams, 1988). Kepedulian perusahaan untuk memperhatikan lingkungan sekitarnya umumnya nampak dari beberapa kebijakan yang dilakukan. Perekrutan karyawan dari lingkungan sekitar tempat usaha misalnya, akan menegaskan identitas perusahaan sebagai memiliki kepedulian sosial dan meningkatkan kelas sosial mereka yang akan menguatkan image yang positif. Sebaliknya, jika perusahaan dalam hal ini UKM mengisolasi diri dari masyarakat sekitar, maka muncul risiko dicap sebagai asosial atau tidak peduli pada orang lain. Hal ini berakibat pada kecenderungan masuk sebagai kategori sosial yang kontras yang dapat menimbulkan social cost bagi perusahaan sendiri dan masyarakat disekitarnya.

Oleh karena itu ketika perusahaan mengemban tanggung jawab sosial seolah menegaskan bahwa perusahaan memiliki identitas sosial yang positif dan berada pada kelas sosial yang relatif terhormat dalam meningkatkan corporate image. Pada mulanya konsep orientasi tersebut dikaji secara empiris pada manajer, tetapi konsep tersebut juga dapat diujikan pada pihak stakeholder lain (Smith, Harrington, dan Dennis, 2001).

Peran dan tanggung jawab sosial perusahaan akan berarti jika pihak-pihak yang berkepentingan dengan perusahaan merasakan manfaat dari kebijakan perusahaan tersebut. Semakin tinggi komitmen UKM pada sebuah identitas sosial tertentu, semakin besar konsistensi antara peran yang diharapkan (role expectations) dan pelaksanaan peran tersebut (role performance). Jika stakeholder mendapatkan manfaat secara sosial 
dari peran dan identitas perusahaan melalui tanggung jawab sosial maka diharapkan semakin kuat image sosial perusahaan. Image sosial yang positif akan sejalan dengan konsistensi dalam melakukan tindakan sosial sekaligus memenuhi harapan masyarakat sekitar. Dengan adanya orientasi tanggungjawab sosial yang dibangun oleh UKM, maka diharapkan akan berdampak pada kinerja sosial perusahaan yang bagus pula. Riset empiris sebelumnya menguji bagaimana stakeholder merespon kinerja sosial perusahaan dengan menilai kemungkinan mereka berinteraksi dengan perusahaan dalam posisi sebagai pekerja (Albinger dan Freeman, 2000), sebagai investor (Sethi, 2005; Sparkes dan Cowton, 2004) dan bahkan sebagai konsumen (Maignan dan Fenell, 2001).

Sikap yang beragam dari stakeholder tentu saja dilandasi oleh kepentingan mereka terhadap organisasi tersebut. Diduga jika orientasi tanggung jawab sosial perusahaan lebih bermuara kepada kinerja ekonomik maka hal tersebut akan sejalan dengan kinerja ekonomik yang tinggi pula. Jika perusahaan memiliki motif kepedulian etika yang tinggi maka pelaku UKM akan menempatkan kebijakan usaha mereka untuk sejalan dengan aspek etika yang berlaku di masyarakat sekitar perusahaan sebagai bagian dari stakeholder perusahaan. Selanjutnya diharapkan terdapat respon positif terhadap kinerja sosial perusahaan yang mencerminkan aspek etika yang tinggi pula. Berdasarkan hal tersebut maka diturunkan hipotesis sebagai berikut:

H1a: Tingkat orientasi ekonomik yang tinggi dari tanggung jawab sosial UKM berpengaruh positif terhadap kinerja sosial perusahaan.

H1b: Tingkat orientasi legal yang tinggi dari tanggung jawab sosial UKM berpengaruh positif terhadap kinerja sosial perusahaan.

H1c: Tingkat orientasi etika dan diskresioner yang yang tinggi dari tanggung jawab sosial UKM berpengaruh positif terhadap kinerja sosial perusahaan.

\section{Hubungan Orientasi Corporate Social Responsibility (CSR) dengan Kinerja Sosial Perusahaan yang Dimoderasi Oleh Ketidak Pastian Lingkungan}

Dalam melihat hubungan antara orientasi tanggungjawab sosial dengan kinerja sosial perusahaan, penelitian ini mencoba melihat faktor kontingensi yang dapat mempengaruhi hubungan tersebut. Dalam kondisi normal, tingkat orientasi yang tinggi terhadap tanggung jawab sosial sebagai sebuah attitude diharapkan akan membawa pada perilaku tanggung jawab sosial yang tinggi pula. Akan tetapi dalam perjalanannya faktor eksternal dapat pula membentuk persepsi yang bisa membawa perubahan perilaku. Menurut paham kontingensi, tidak ada hubungan yang bersifat universal yang berlaku untuk seluruh keadaan. Fit antara organisasi dengan lingkungannya hanya tercipta dengan optimal dengan peran faktor situasional yang relevan pada saat itu. Oleh karenanya, dalam penelitian ini faktor kontingen berupa ketidakpastian lingkungan dipertimbangkan sebagai moderasi hubungan antara orientasi individu dalam memandang tanggung jawab sosial perusahaan dan persepsi kinerja sosial perusahaan. Ketidakpastian lingkungan dalam hal ini dikaitkan dengan situasi lingkungan pasar dan kompetisi dengan pesaing. Dalam struktur pasar usaha kecil dan menengah yang sangat banyak pelakunya, persaingan antar perusahaan adalah sangat ketat. Para pelaku usaha kecil dan menengah seringkali dihadapkan pada intensitas persaingan yang tinggi dan memiliki daya tawar yang lemah terhadap pasar. Jika faktor persaingan yang tinggi dan dibarengi dengan subsitusi 
produk oleh pesaing yang juga tinggi mengakibatkan ketidakpastian lingkungan juga tinggi. Hal ini akan memaksa para pelaku usaha kecil dan menengah untuk berfokus pada upaya mengejar aspek ekonomik berbanding memperhatikan aspek sosial dan lingkungan. Berdasarkan hal tersebut maka diturunkan hipotesis sebagai berikut:

H2: Ketidakpastian lingkungan yang tinggi akan memperlemah hubungan antara orientasi individu tanggung jawab sosial perusahaan dengan kinerja sosial perusahaan.

\section{METODE PENELITIAN}

\section{Populasi dan Sampel}

Penelitian ini merupakan penelitian persepsi para manajer pada usaha berskala kecil dan menengah (UKM) di Jawa Tengah. Populasi penelitian ini adalah perusahaan skala kecil dan menengah yang berada di Jawa Tengah sebagai sentra perkembangan UKM nasional. Sedangkan untuk keperluan penelitian, pengambilan sampel dilakukan terhadap para manajer dari usaha kecil dan menengah yang berada di kota Semarang, kabupaten Semarang, Salatiga, Kendal, Demak, dan Kudus. Sedangkan perusahaan yang menjadi target sampel penelitian ini diasumsikan merupakan perusahaan yang sedang berkembang menjadi perusahaan skala menengah dimana sudah mulai ada orientasi terhadap tanggung jawab sosial perusahaan.

Satu set kuesioner telah dibagikan pada objek penelitian untuk diisi. Para responden penelitian diinstruksikan untuk membaca kuesioner secara menyeluruh sebelum mengisi pertanyaan yang diberikan. Bagian pertama kuesioner berisikan rangkaian informasi mengenai karakteristik responden dan usaha mereka. Sedangkan bagian kedua kuesioner merupakan rangkaian pernyataan yang menggambarkan orientasi tanggung jawab sosial perusahaan. Selanjutnya pada bagian ketiga kuesioner berisikan poin-poin deskripsi kinerja sosial perusahaan yang telah dilakukan terhadap berbagai stakeholder. Bagian keempat sebagai bagian terakhir mencoba menjelaskan ketidakpastian lingkungan dari persepsi perusahaan.

\section{Definisi Operasional dan Pengukuran Variabel.}

\section{Persepsi Kinerja Sosial Perusahaan.}

Dalam penelitian ini yang menjadi variabel dependen adalah persepsi kinerja sosial perusahaan (Corporate Social Performance). Kinerja sosial perusahaan didefinisikan sebagai tindakan sosial yang telah dilakukan oleh perusahaan dalam berinteraksi dengan masyarakat, karyawan, investor, konsumen, pemasok, serta lingkungannya (Rettab et al, 2009). Instrumen diadaptasi dari Maignan dan Ferrel (2004). Keenam dimensi tanggung jawab sosial perusahaan dalam kaitannya dengan stakeholder dapat dirinci menjadi 26 item pernyataan. Kemudian responden dalam hal ini para pelaku utama usaha kecil dan menengah mempersepsikan kinerja sosial mereka yang mencerminkan apa yang telah dilakukan perusahaan kedalam skala penilaian likert 5 poin. Rentang poin dari sangat tidak setuju sampai sangat setuju.

\section{Orientasi Perusahaan Terhadap Tanggung Jawab Sosial Perusahaan}

Variabel independen utama dalam penelitian ini adalah orientasi perusahaan terhadap tanggung jawab 
sosial perusahaan. Instrumen diadaptasi dari Aupperle (1984) dan Aupperle et.al (1985) yang merupakan instrumen yang populer dalam mengukur orientasi individu terhadap CSR selama lebih dari dua puluh tahun terakhir. Instrumen Aupperle sendiri dikembangkan berdasarkan framework tanggung jawab sosial yang dkembangkan oleh Carroll (1979) yang meliputi aspek ekonomi, hukum, etika, dan diskresioner. Dalam instrumen ini digunakan skala likert 5 poin untuk menilai tingkat orientasi tanggung jawab sosial dari responden untuk setiap set paparan aspek CSR. Total terdapat 10 set paparan aspek CSR dimana responden dapat memiliki preferensi dan penekanan yang berbeda pada setiap aspek CSR yang ada. Keempat butir pernyataan pada setiap set mewakili empat aspek tanggung jawab sosial perusahaan. Oleh karena itu, total skor dari setiap empat aspek tanggung jawab perusahaan dihitung untuk melihat orientasi CSR dari responden (Ibrahim dan Angelidis, 1993).

\section{Ketidakpastian lingkungan}

Variabel ini merupakan variabel kontingensi yang merupakan persepsi manajer tentang faktor eksternal mengenai prediktabilitas pasar dan kompetitor. Semakin tinggi kompetisi pasar dan dinamika produk di pasar, maka semaki tinggi ketidakpastian lingkungan. Instrumen pertanyaan diadaptasi dari Desarbo et al. (2005). Instrumen dipilih karena item-item pertanyaan yang digunakan lebih ringkas dan mudah dipahami dalam mengukur tingkat ketidakpastian dari pasar dan kompetitor. Item diukur melalui skala likert lima poin yang mengukur tingkat prediksi dari lingkungan pasar dan kompetitor.

\section{Analisis Statistik}

Pengujian variabel secara statistik dapat dibagi menjadi beberapa tahap. Pada tahap awal dilakukan pengujian validitas dan reliabilitas instrumen. Analisis korelasi rank spearman serta cronbach alpha akan dilihat untuk menentukan apakah instrumen cukup valid dan reliabel. Perbaikan instrumen melalui pilot study juga akan dilakukan. Selanjutnya dilakukan uji asumsi klasik untuk mendukung uji regresi berganda. Terdapat empat asumsi klasik yang menjadi perhatian yaitu uji normalitas, homokesdastisitas, multikolinearitas dan autokorelasi. Selanjutnya pengujian hipotesis dilakukan melalui analisis regresi berganda. Persamaan regresinya dapat digambarkan sebagai berikut:

$$
K S P_{i}=\beta_{0}+\beta_{1} C S R O+\beta_{2} P E U+\beta_{3} C S R O * P E U+\epsilon
$$

Keterangan:

- KSP : Kinerja Sosial Perusahaan

- CSRO : Orientasi CSR

- PEU : Ketidakpastian lingkungan

\section{HASIL DAN PEMBAHASAN}

\section{Deskripsi Responden}

Obyek penelitian yang menjadi target sampel adalah usaha kecil dan menengah yang terdapat di Jawa Tengah. Pengambilan data dipusatkan pada industri kecil dan menengah yang berada di wilayah eks 
karesidenan Semarang. Sebanyak 300 kuesioner disebarkan kepada para pelaku usaha kecil dan menengah yang berada di lokasi sekitar Semarang, Ungaran, Salatiga, Kendal, Demak, dan Kudus. Para pengusaha di lingkungan industri kecil dan menengah dapat dibagi menjadi tiga kategori yaitu usaha kecil dan menengah yang bergerak di sektor perdagangan, sektor jasa maupun sektor manufaktur. Dari sekitar 300 kuesioner yang dibagikan, hasil akhir menunjukkan hanya 115 kuesioner yang layak untuk diteruskan dalam analisis. Jumlah kuesioner sebanyak 115 yang digunakan untuk analisis didominasi oleh sektor perdagangan yang terdiri dari 72 responden atau 63\% dari seluruh sampel. Peringkat kedua disusul oleh sektor jasa sebanyak 27 responden atau 23\% dari sampel. Sektor manufaktur memiliki 16 responden atau 14\% dari sampel. Deskripsi lengkap tentang jumlah dan proporsi responden yang dilihat dari berbagai karakteristik dapat dilihat dalam tabel 4.2.

Berdasarkan profil responden yang terangkum dalam tabel 4.2, karakteristik utama sampel antara lain didominasi oleh sektor UKM yang memiliki omset 200 juta rupiah kebawah (82\%), memiliki karyawan kurang dari sepuluh orang (79\%), umur perusahaan yang relatif muda yaitu lima tahun kebawah (48\%) serta berorientasi pada pasar domestik (92\%). Melihat bermacam karakteristik diatas, maka tidaklah mengherankan apabila usaha kecil dan menengah masih memiliki kesempatan yang luas untuk lebih berkembang lagi.

\section{Hasil Analisis dan Pembahasan}

Hasil analisis statistika akan disajikan secara berurutan dari statistika deskriptif, uji asumsi klasik dan hasil uji hipotesis. Statistika deskriptif yang ditunjukkan di sini meliputi nilai minimum, maksimum, mean, serta standar deviasi dan dapat dilihat dalam tabel 4.3. Standar deviasi cukup kecil karena tidak lebih dari 30\% rata-ratanya, sehingga data ini diharapkan dapat digunakan untuk merepresentasikan variabel sehinggga interpretasi data akan menggambarkan kondisi yang mendekati sesungguhnya.

Analisis berikutnya berkaitan dengan uji kualitas data. Data penelitian yang merupakan data primer dengan instrumen kuesioner merupakan data yang bersifat subyektif. Oleh karena itu, kualitas data perlu diuji dengan uji validitas dan reliabilitas. Pengujian reliabilitas dimaksudkan untuk melihat konsistensi jawaban antar responden dalam mengisi item-item pertanyaan. Hasil uji reliabilitas dapat dilihat pada tabel 4.4

Hasil tabel 4.4 diatas menunjukkan bahwa nilai cronbach alpha semuanya menunjukkan angka diatas 0,6 yang berarti bahwa data responden reliabel. Berikutnya dilakukan pengujian validitas melalui pearson correlation matrix. Jika korelasi antara masing-masing item dengan skor total item menunjukkan hasil yang signifikan, maka dikatakan bahwa instrumennya memang valid. Berdasarkan hasil pengujian korelasi, didapatkan bahwa korelasi item to total item score correlation semuanya signifikan, yang berarti bahwa data penelitian ini adalah valid.

Langkah berikutnya adalah melakukan uji asumsi klasik. Pengujian awal dilakukan melalui uji normalitas, melalui uji Kolmogorov Smirnov. Distribusi dari residual persamaan regresi harus memiliki distribusi secara normal. Selanjutnya hasil pengujian dapat dilihat pada tabel 4.5 .

Hasil uji normalitas kolmogorov smirnov dari tabel 4.5 diatas menunjukkan bahwa signifikasi residual semuanya tidak signifikan, yang berarti bahwa distribusi dari residual adalah bersifat normal. Sedangkan asumsi klasik yang lain adalah homokesdatisitas. Pengujian apakah data regresi mengandung heterokesdatisitas atau 
tidak melalui pengujian grafik plot seperti yang ditunjukkan gambar 4.1 dibawah ini.

Berdasarkan ilustrasi grafik 4.1 diatas, terjadi penyebaran titik secara acak dan oleh karena itu dapat disimpulkan tidak terjadi gejala heterokesdastisitas.

\section{Hasil Uji Hipotesis}

Pengujian hipotesis dilakukan dengan menggunakan dengan menggunakan moderated regression analysis, yaitu pengujian regresi berganda dengan memasukkan variabel interaksi. Bagian awal dari pengujian regresi dimulai dengan hasil dari goodness of fit dari model persamaan regresi yang dapat dilihat pada tabel 4.6

Hasil uji statistik untuk melihat goodness of fit data berdasarkan tabel 4.6 menunjukkan hasil bahwa secara keseluruhan model regresi fit dan signifikan. Dapat dikatakan bahwa secara bersama-sama variabel independen memiliki pengaruh terhadap variabel dependen. Seberapa besar pengaruh dari variabel independen terhadap variabel dapat dilihat dari koefisien determinasi atau $\mathrm{R}^{2}$. Secara ringkas hasil koefisien determinasi dapat dilihat pada tabel 4.7.

Dari tabel 4.7 diatas dapat diketahui nilai adjusted R-square sebesar 13\% yang berarti bahwa sekitar 13\% variasi dari variabel dependen dijelaskan oleh variabel independen. Sedangkan sisanya dijelaskan oleh faktor luar diluar model. Untuk mengetahui apakah hipotesis penelitian diterima atau ditolak maka perlu diketahui hasil pengujian statistik seperti yang terangkum dalam tabel 4.8 .

Hasil dari tabel 4.8 diatas menunjukkan bahwa terdapat beberapa variabel yang signifikan. Orientasi etika perusahaan memiliki hubungan yang positif dan signifikan terhadap kinerja sosial perusahaan pada level 1 $\%$. Sedangkan orientasi hukum justru memiliki hubungan yang negatif dan signifikan terhadap kinerja sosial perusahaan.

Interaksi antara variabel independen dan variabel moderating menghasilkan hubungan yang signifikan untuk dua interaksi. Interaksi antara orientasi etika dan ketidakpastian lingkungan memiliki hubungan yang negatif terhadap kinerja sosial perusahaan pada level 1\%. Sedangkan interaksi antara orientasi hukum dengan ketidakpastian lingkungan memiliki hubungan yang positif dengan kinerja sosial perusahaan pada level 5\%. Secara umum dapat dikatakan bahwa variabel moderasi ketidakpastian lingkungan memiliki peran tidak saja memperlemah hubungan antara variabel independen dan variabel dependen, tetapi juga membalik arah hubungan kedua variabel tersebut.

\section{Pembahasan}

Hasil analisis menunjukkan bahwa hipotesis 1 didukung secara parsial. Dari keempat aspek orientasi tanggungjawab sosial, hanya orientasi etika yang menunjukkan hubungan yang positif dan signifikan terhadap kinerja sosial perusahaan. Sedangkan orietasi laba dan sosial tidak signifikan meskipun memiliki koefisien yang positif. Artinya bahwa dalam fase usaha kecil dan menengah, orietasi laba mungkin bukan merupakan faktor yang paling utama dalam menjalankan fungsi tanggung jawab sosial perusahaan. Kiprah UKM dalam menjalankan roda perekonomian justru menekankan pada pertimbangan etis dalam memainkan 
peran sosial perusahaan. Hal ini mungkin disebabkan oleh gaya manajemen perusahaan yang masih bersifat kekeluargaan. Budaya yang bersifat kekeluargaan memberikan pengaruh dalam sudut pandang pelaku UKM dalam menjalankan bisnisnya.

Hasil yang agak mengejutkan didapatkan dari hubungan antara orientasi hukum dan kinerja sosial perusahaan yang bersifat negatif. Penjelasan dari fenomena ini adalah bahwa ketika perusahaan masih dalam skala kecil dan dikelola secara kekeluargaan, maka formalitas menjadi suatu hal yang dianggap masih membelenggu. Pendekatan hukum yang berorientasi pada kebijakan yang bersifat kaku dan mengikat dirasakan tidak cocok dengan pola kehidupan pelaku UKM yang menjalankan bisnisnya secara lebih informal. Disamping itu, para pelaku UKM mungkin belum terlalu paham mengenai ketaatan terhadap regulasi-regulasi dari pemerintah karena memang belum merasa urgen untuk taat secara rigid terhadap aturan hukum. Bahkan ketidakpastian hukum yang terjadi dan dan ketidakadilan dalam penegakan hukum membuat para pelaku UKM cenderung resisten dalam menaati aturan hukum yang berlaku.

Peran dari ketidakpastian lingkungan yang cukup kuat dalam mengubah arah hubungan variabel independen dan dependen menunjukkan kontribusi faktor eskternal yang signifikan terhadap kehidupan bisnis UKM. Ketika para pelaku UKM membangun bisnis mereka dari skala yang kecil, eksistensi kesinambungan bisnis mereka masih belum stabil benar. Kondisi ketidakpastian lingkungan yang tinggi akan membuat mereka berpikir ulang dalam mempertahankan orietasi tanggungjawab sosial mereka. Orientasi etika yang meskipun mengikat secara moral, sebenarnya mencerminkan kesadaran pribadi yang bersifat diskresioner. Ketika para pelaku UKM berbenturan dengan kondisi ketidakpastian lingkungan yang tinggi, mereka lebih memilih untuk mempertahankan jalur bisnis meskipun dengan demikian akan menggerus aspek etika.

Sebaliknya dalam kondisi ketidakpastian yang tinggi ternyata juga mengubah orientasi hukum pelaku UKM untuk lebih bersikap comitted terhadap aturan hukum yang ada. Ketidakpastian lingkungan yang tinggi akan menyebabkan para pelaku UKM untuk lebih hati-hati dalam melangkah agar jangan sampai terkena jerat hukum. Dengan demikian, meskipun ada aspek keterpaksaan maka para pelaku bisnis UKM akan lebih berfikir secara rasional dengan lebih mempertimbangkan aspek hukum.

\section{SIMPULAN, KETERBATASAN DAN SARAN}

\section{Simpulan}

Berdasarkan hasil penelitian maka dapat disimpulkan bahwa orientasi etika perusahaan berhubungan positif dengan kinerja sosial perusahaan. Sedangkan orientasi hukum berhubungan negatif dengan kinerja sosial perusahaan. Variabel moderator ketidakpastian lingkungan dalam interaksinya dengan orientasi perusahaan terhadap tanggung jawab sosial menghasilkan dua interaksi yang signifikan. Ketidakpastian yang tinggi menjadikan orientasi etika berhubungan negatif terhadap kinerja sosial perusahaan. Disamping itu pada ketidakpastian yang tinggi orientasi hukum berbalik menjadi positif terhadap kinerja sosial perusahaan.

\section{Keterbatasan dan Saran Penelitian Mendatang}

Keterbatasan penelitian ini adalah keterbatasan sampel yang diperoleh. Dikarenakan hanya memperoleh 
sampel dari wilayah Semarang dan sekitarnya, maka kesimpulan hasil penelitian ini tidak dapat digeneralisir. Sedangkan keterbatasan yang kedua berkaitan dengan instrumen yang relatif rumit dalam mengukur orientasi tanggung jawab sosial perusahaan. Pengukuran setiap konstruk orientasi memerlukan sepuluh item yang tersebar dalam beberapa pertanyaan. Hal ini mengakibatkan kebingungan responden dalam menjawab pertanyaan.

Berdasarkan keterbatasan diatas, maka untuk penelitian mendatang perlu mempertimbangkan beberapa hal. Pertama, desain instrumen mungkin dapat dimodifikasi agar lebih sederhana, untuk menangkap pengaruh setiap aspek orientasi dan aspek kinerja. Penelitian yang baik mestinya bersifat parsimoni dan tidak rumit. Oleh karena itu penelusuran terhadap instrumen pengukuran alternatif layak untuk dicoba. Selanjutnya agar sampel penelitian perlu lebih diperluas dengan mempertimbangkan keterwakilan sektor industri kecil dan menengah yang beraneka ragam.

\section{DAFTAR PUSTAKA}

Albinger, H. S., \& Freeman, S. J. (2000). Corporate Social Performance and Attractiveness as an Employer to Different Job Seeking Populations. Journal of Business Ethics, 28(3), 243

Aupperle, K. E. (1984). An Empirical Measure of Corporate Social Orientation. In L. E. Preston (Ed.), Research in Corporate Social Performance and Policy (Vol. 6, pp. 27-54). Greenwich, CT: JAI.

Aupperle, K. E., Carroll, A. B., \& Hatfield, J. D. (1985). An Empirical Examination of the Relationship Between Corporate Social Responsibility and Profitability. Academy of Management Journal, 28(2), 446-463.

Carroll, A. (1979). Three-Dimensional Conceptual Model of Corporate Performance. Academy of Management Review (4), pp.497-505.

Carroll, A. B. (1991). The pyramid of corporate social responsibility: Toward the moral management of organizational stakeholders. Business Horizons, 34(4), pp. $39-48$

Cohen, J. R., Pant, L. W., \& Sharp, D. J. (1998). The Effect of Gender and academic Discipline Diversity on the Ethical Evaluations, Ethical Intentions and Ethical Orientation of Potential Public Accounting Recruits. Accounting Horizons (12), pp. 250-270.

DeSarbo WS, Di Benedetto CA, Song M, Sinha I. (2005). Revisiting the Miles and Snow strategic framework: uncovering relationships between strategic types, capabilities, environmental uncertainty, and firm performance. Strategic Management Journal 26: 47-74.

Donaldson, T. \& Preston, L. (1995). The Stakeholder Theory of the Corporation: Concepts, Evidence, and Implications. Academy of Management Review, (20), pp. 65-91.

Donaldson, T. (2002) 'The stakeholder revolution and the clarkson principles', Business Ethics Quarterly 12(2): 107.

Freeman, R. E. (1984). Strategic management: a stakeholder approach. Boston: Pitman Publishing, Inc.

Freeman, R. E. (1994). The politics of stakeholder theory: Some future directions. Business Ethics Quarterly, 4(4), 
409-422.

Hogg, M. A., \& Abrams, D. (1990). Social motivation, self-esteem and social identity. In D. Abrams \& M. A. Hogg (Eds.), Social identity theory: Constructive and critical advances (pp. 28-47). London: Harvester Wheatsheaf.

Ibrahim, N. A, \& Angelidis, J. A. (1993). Corporate social responsibility: A comparative analysis of perceptions of top executives and business students. The Mid - Atlantic Journal of Business, 29(3), 303.

Maignan, I. \& Ferrell, O. (2004). Corporate Social Responsibility and Marketing: An Integrative Framework. Academy of Marketing Science 32, 3-19.

Maignan, I. (2001). Consumers' perception of corporate social responsibilities: Acrosscultural comparison. Journal of Business Ethics, 30(1), 57-72.

Perry, P., \& Towers, N. 2009. Determining the antecedents for a strategy of corporate social responsibility by small- and medium-sized enterprises in the UK fashion apparel industry. Journal of Retailing and Consumer Services 16, 377-385

Republik Indonesia. (2007). Undang-undang Perseroan Terbatas 2007 dan Penjelasannya. Penerbit Gradien Mediatama.

Rettab, B., Brik A.B., \& Mellahi,K. (2009). A study of management perceptions of the impact of corporate social responsibility on organizational performance in emerging economies: the case of Dubai. Journal of Business Ethics.89. 371-390

Sethi, P.S. (2005). Investing in Socially Responsible Companies is a Must for Public Pension Funds-Because There is no Better Alternative. Journal of Business Ethics (56), 99-129.

Smith, W. J., Wokutch, R. E., Harrington, K. V., \& Dennis, B. S. (2001). An examination of the influence of diversity and stakeholder role on corporate social orientation. Business and Society, 40(3), 266-294.

Smith, W. J., Wokutch, R. E., Harrington, K. V., \& Dennis, B. S. (2004). Organizational attractiveness and corporate social orientation: Do our values influence our preference for affirmative action and managing diversity? Business and Society, (43), pp. 69-96.

Sparkes, R., \& Cowton, C.J. (2004). The Maturing of Socially Responsible Investment: a Review of the Developing Link With Corporate Social Responsibility. Journal of Business Ethics (52). 45-57.

Tajfel, H., \& Turner, J. C. (1986). The social identity theory of intergroup behavior. In S.Worchel \& W. G. Austin (Eds.), The psychology of intergroup relations 7-24. 
Lampiran

Tabel 4.2.

Profil Responden

\begin{tabular}{|c|c|c|c|c|c|c|}
\hline \multirow{2}{*}{ Karakteristik } & \multirow{2}{*}{ Kategori } & \multicolumn{3}{|l|}{ Jenis Usaha } & \multirow{2}{*}{ Jumlah } & \multirow{2}{*}{$\%$} \\
\hline & & Perdagangan & Jasa & Manufaktur & & \\
\hline \multirow[t]{5}{*}{ Omset } & $\leq 200 \mathrm{jt}$ & 62 & 22 & 10 & 94 & $82 \%$ \\
\hline & $201-500 \mathrm{jt}$ & 6 & 2 & 4 & 12 & $10 \%$ \\
\hline & 501- 1 milyar & 2 & 1 & 1 & 4 & $3 \%$ \\
\hline & $>1$ Milyar & 2 & 2 & 1 & 5 & $4 \%$ \\
\hline & Jumlah & 72 & 27 & 16 & 115 & \\
\hline \multirow[t]{4}{*}{ Karyawan } & $<10$ org & 59 & 22 & 10 & 91 & $79 \%$ \\
\hline & $11-30$ org & 11 & 2 & 2 & 15 & $13 \%$ \\
\hline & $>30$ org & 2 & 3 & 4 & 9 & $8 \%$ \\
\hline & Jumlah & 72 & 27 & 16 & 115 & \\
\hline \multirow[t]{4}{*}{ Umur } & $1-5$ thn & 32 & 16 & 7 & 55 & $48 \%$ \\
\hline & 6-10 thn & 21 & 6 & 1 & 28 & $24 \%$ \\
\hline & $>10$ thn & 19 & 5 & 8 & 32 & $28 \%$ \\
\hline & Jumlah & 72 & 27 & 16 & 115 & \\
\hline \multirow[t]{3}{*}{ Ekspor } & $\mathrm{Ya}$ & 4 & 2 & 3 & 9 & $8 \%$ \\
\hline & Tdk & 68 & 25 & 13 & 106 & $92 \%$ \\
\hline & Jumlah & 72 & 27 & 16 & 115 & \\
\hline
\end{tabular}

Sumber: Data primer yang diolah

Tabel 4.3.

Statistik Deskriptif

\begin{tabular}{lrrrl}
\hline & Minimum & Maximum & Mean & Std. Deviation \\
\hline Orientasi Laba & 30.00 & 50.00 & 39.78 & 4.408 \\
\hline Orientasi Etik & 28.00 & 48.00 & 38.96 & 3.447 \\
\hline Orientasi Hukum & 25.00 & 50.00 & 38.51 & 4.025 \\
\hline Orientasi Sosial & 29.00 & 50.00 & 37.82 & 4.244 \\
\hline Kinerja Sosial Total & 6.00 & 28.25 & 21.46 & 3.272 \\
\hline Kinerja Sosial Masyarakat & 4.00 & 20.00 & 12.43 & 3.084 \\
\hline Kinerja Sosial Lingkungan & 4.00 & 20.00 & 13.32 & 2.585 \\
\hline Kinerja Sosial Karyawan & 1.67 & 20.00 & 15.55 & 3.402 \\
\hline Kinerja Sosial Investor & 4.00 & 20.00 & 12.74 & 4.575 \\
\hline Kinerja Sosial Konsumen & 4.00 & 20.00 & 17.55 & 2.407 \\
\hline Kinerja Sosial Suplier & 5.00 & 25.00 & 17.48 & 3.994 \\
\hline Ketidakpastian Lingkungan & 10.00 & 44.00 & 30.39 & 5.815 \\
\hline
\end{tabular}


Tabel 4.4.

Uji reliabilitas data

\begin{tabular}{ll}
\hline Variabel & Nilai Cronbach Alpha \\
\hline Orientasi Laba & 0.783 \\
\hline Orientasi Etik & 0.646 \\
\hline Orientasi Hukum & 0.757 \\
\hline Orientasi Sosial & 0.704 \\
\hline Kinerja Sosial Masyarakat & 0.796 \\
\hline Kinerja Sosial Lingkungan & 0.661 \\
\hline Kinerja Sosial Karyawan & 0.781 \\
\hline Kinerja Sosial Investor & 0.943 \\
\hline Kinerja Sosial Konsumen & 0.890 \\
\hline Kinerja Sosial Suplier & 0.845 \\
\hline Ketidakpastian Lingkungan & 0.710 \\
\hline
\end{tabular}

Tabel 4.5

Uji Normalitas Kolmogorov Smirnov

\begin{tabular}{llr}
\hline & & Unstandardized Residual \\
\hline $\mathrm{N}$ & & 115 \\
Normal Parameters & Mean & 0.00 \\
$(\mathrm{a}, \mathrm{b})$ & Std. Deviation & 3.06 \\
& Absolute & 0.08 \\
Most Extreme Differences & Positive & 0.04 \\
& Negative & $0.08)$ \\
& & 0.81 \\
Kolmogorov-Smirnov Z & & $\mathbf{0 . 5 3}$ \\
Asymp. Sig. (2-tailed) & & \\
& & \\
\hline
\end{tabular}

\section{Gambar 4.1.}

Plot grafik regresi

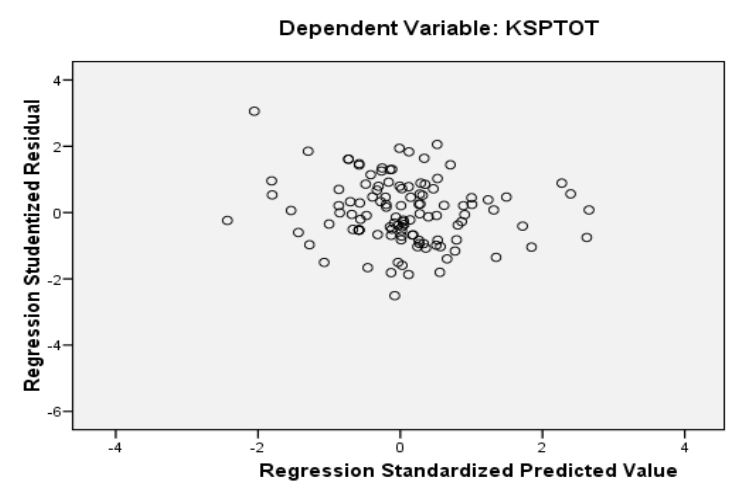


Tabel 4.6

Goodness of fit

\begin{tabular}{lrrrrr}
\hline & Sum of Squares & Df & & Mean Square & \multicolumn{2}{c}{ Sig. } \\
\hline Regression & 242.204 & 9 & 26.912 & 2.888 & .004 \\
Residual & 978.463 & 105 & 9.319 & & \\
Total & 1220.666 & 114 & & & \\
\hline
\end{tabular}

Tabel 4.7

Koefisien Determinasi

\begin{tabular}{|c|c|c|c|c|c|c|}
\hline Model & $\mathrm{R}$ & & R Square & $\begin{array}{l}\text { Adjusted R } \\
\text { Square }\end{array}$ & $\begin{array}{l}\text { Std. Error of the } \\
\text { Estimate }\end{array}$ & Durbin-Watson \\
\hline & & .445 & . 198 & .130 & 3.05265 & 1.711 \\
\hline
\end{tabular}

Tabel 4.8

Hasil Uji hipotesis orientasi tanggung jawab sosial dan kinerja sosial perusahaan dengan ketidakpastian lingkungan sebagai Variabel Moderating

\begin{tabular}{|c|c|c|c|c|c|}
\hline & \multicolumn{2}{|c|}{$\begin{array}{l}\text { Unstandardized } \\
\text { Coefficients }\end{array}$} & \multirow{2}{*}{$\begin{array}{l}\text { Standardized } \\
\text { Coefficients } \\
\text { Beta }\end{array}$} & \multirow[t]{2}{*}{$\mathrm{t}$} & \multirow[t]{2}{*}{ Sig. } \\
\hline & B & Std. Error & & & \\
\hline Constant & -12.511 & 20.528 & & -.609 & .544 \\
\hline Orientasi laba & .487 & .449 & .656 & 1.084 & .281 \\
\hline Orientasi etik & 1.547 & .512 & 1.630 & 3.021 & $.003^{* * *}$ \\
\hline Orientasi hukum & -1.125 & .534 & -1.384 & -2.109 & $.037^{* *}$ \\
\hline Orientasi sosial & -.118 & .440 & -.153 & -.269 & .789 \\
\hline Ketidakpastian lingk. & .791 & .668 & 1.406 & 1.184 & .239 \\
\hline INTERLABA & -.012 & .014 & -1.006 & -.818 & .415 \\
\hline INTERETIK & -.050 & .017 & -4.032 & -3.021 & $.003^{* * *}$ \\
\hline INTERHKM & .039 & .017 & 3.045 & 2.263 & $.026^{* *}$ \\
\hline INTERSOC & .005 & .015 & .407 & .353 & .725 \\
\hline
\end{tabular}

